\title{
EDUKASI PERILAKU HIDUP BERSIH DAN SEHAT KEPADA MASYARAKAT DESA AIR SALOBAR UNTUK MENCEGAH PENYEBARAN COVID-19
}

\author{
Melda Yunita ${ }^{1)}$, Eka Astuti1), Elpira Asmin'1), Morgan Ohiwal'2), Sukmawati Nurdin ${ }^{3)}$ \\ ${ }^{1)}$ Fakultas Kedokteran, Universitas Pattimura, Ambon, Indonesia \\ 2)Universitas Muhammadiyah Maluku, Ambon, Indonesia \\ 3)Universitas Muhammadiyah Sorong, Sorong, Indonesia \\ Corresponding author: Melda Yunita \\ E-mail : melda.yunita@fk.unpatti.ac.id
}

Diterima 09 Juli 2021, Direvisi 24 Juli 2021, Disetujui 25 Juli 2021

\begin{abstract}
ABSTRAK
Serangan dari wabah Corona Virus atau Covid-19 telah menyebar di seluruh level wilayah Indonesia dan mengakibatkan banyak korban jiwa. Perilaku hidup bersih dan sehat (PHBS) perlu diterapkan di tengah situasi pandemi ini guna mencegah penyebaran Covid-19, khususnya di Desa Air Salobar mengingat di desa tersebut belum pernah dilakukan penyuluhan ataupun sosialisasi mengenai PHBS. Kegiatan ini bertujuan untuk mengedukasi masyarakat Desa Air Salobar mengenai pentingnya menerapkan PHBS untuk mencegah diri dan keluarga terhindar dari infeksi Covid-19. Edukasi diberikan kepada 25 orang masyarakat Desa Air Salobar RT/RW 003/005 Kecamatan Nusaniwe Ambon. Materi disampaikan secara lisan dengan metode ceramah menggunakan LCD/Proyektor, diikuti sesi diskusi atau Focus Group Discussion (FGD), dan demonstrasi cara mencuci tangan yang baik dan benar dan praktikknya oleh responden. Hasil kegiatan menunjukkan bahwa edukasi berjalan dengan lancar dan diikuti antusiasme dari masyarakat Desa Air Salobar, dibuktikan dengan banyaknya masyarakat yang bertanya saat sesi diskusi dan aktifnya responden dalam demonstrasi dan praktik mencuci tangan yang baik dan benar bersama fasilitator.
\end{abstract}

Kata kunci : edukasi; covid-19; PHBS; FGD.

\begin{abstract}
The attack from the Corona Virus or Covid-19 outbreak has spread across all levels of Indonesia and resulted in many deaths. Clean and healthy living behavior (PHBS) needs to be implemented in the midst of this pandemic situation to prevent the spread of Covid-19, especially in Air Salobar Village considering that there has never been any counseling or socialization about PHBS. This activity aims to educate the people of Air Salobar Village about the importance of implementing PHBS to prevent themselves and their families from being infected with Covid-19. Education was given to 25 people in Air Salobar Village, RT/RW 003/005, Nusaniwe Subdistrict, Ambon. The material was delivered orally using a lecture method using an LCD/Projector, followed by a discussion session or Focus Group Discussion (FGD), and demonstrations on how to wash hands properly and in practice by respondents. The results of the activity showed that education went smoothly and was followed by enthusiasm from the people of Air Salobar Village, as evidenced by the many people who asked questions during the discussion session and the active participation of respondents in demonstrations and good and correct hand washing practices with the facilitator.
\end{abstract}

Keywords : education; covid-19; PHBS; FGD.

\section{PENDAHULUAN}

Beberapa tahun terakhir ini, serangan dari wabah Corona Virus atau Covid-19 begitu masif dan telah menyebar di berbagai belahan dunia termasuk Indonesia, bahkan penyebarannya sudah mencapai hampir di seluruh provinsi, kabupaten dan pelosok desa serta menimbulkan dampak yang sangat mengkhawatirkan. Data Kemenkes (2021) per 24 Juni melaporkan bahwa sebanyak 2.053.995 orang terinfeksi covid dan telah merenggut sebanyak 55.949 korban jiwa.
Menurut (Singhal, 2021), virus ini menyebar dengan berbagai cara, seperti melalui droplet saat penderita batuk, bersin, berbicara, dan kontak langsung dengan penderita atau benda di sekitar. Gejala yang ditimbulkan saat seseorang terpapar Covid-19 diantaranya ialah batuk dan nyeri pada tenggorokan, demam dengan suhu $>38^{\circ} \mathrm{C}$, sesak napas, flu yang disertai hidung tersumbat, nyeri otot, nyeri kepala, diare, pneumonia, bahkan berujung pada kematian (Huang et al., 2020). Berbagai cara telah dilakukan untuk mencegah 
penyebaran covid-19, salah satunya dengan menjaga perilaku hidup bersih dan sehat.

Perilaku Hidup Bersih dan Sehat (PHBS) merupakan serangkaian perilaku yang dilakukan untuk menjaga kesehatan di berbagai level baik perorangan, keluarga, masyarakat, dan lingkungan yang bertujuan untuk meningkatkan taraf kesehatan baik secara fisik, mental, spiritual, maupun sosial. Beberapa pola perilaku hidup bersih dan sehat yang dapat dilakukan guna mencegah serangan Covid-19 diantaranya ialah menjaga kebersihan tubuh sebelum dan keluar rumah, menjaga jarak dengan orang lain, menerapkan etika batuk, dan mencuci tangan dengan baik dan bersih (Razi et al., 2020). Beberapa contoh kongkrit dari perilaku sehat yaitu perilaku proaktif dalam menjaga kesehatan, mencegah risiko timbulnya penyakit, melindungi diri dari ancaman penyakit serta berperan aktif dalam upaya memelihara kesehatan. PHBS merupakan perilaku yang harus dipraktikkan secara kontinyu agar menjadi suatu kebiasaan. Partisipasi seluruh anggota keluarga dalam menerapkan PHBS mendukung terbentuknya lingkungan yang sehat dan kondusif sehingga bermanfaat baik dalam lingkungan keluarga maupun masyarakat.

Salah satu program yang telah dikembangkan oleh pemerintah guna memutus penyebaran Covid-19 ialah dengan menerapkan protokol kesehatan. Namun, kurangnya pemahaman masyarakat, khususnya di Desa Air Salobar, mengenai pentingnya menjaga PHBS untuk menghindari penyebaran Covid-19 masih menjadi kendala yang perlu diatasi. Desa Air Salobar merupakan suatu desa yang terletak di Kelurahan Nusaniwe, Kecamatan Nusaniwe, Kota Ambon, Provinsi Maluku. Berdasarkan hasil survey lokasi dan wawancara yang dilakukan dengan Ketua RT/RW 03/05 Desa Air Salobar dan beberapa masyarakat di sana, diketahui bahwa masyarakat setempat belum pernah mendapatkan penyuluhan ataupun sosialisasi mengenai PHBS sehingga cenderung menganggap remeh persoalan ini seperti tidak terbiasa mencuci tangan sebelum dan sesudah keluar rumah dan tidak terbiasa menyediakan hand sanitizer saat berpergian, bahkan kurang menyadari pentingnya meggunakan masker. Oleh karena itu, fasilitator tertarik untuk memberikan edukasi kepada masyarakat Desa Air Salobar mengenai pentingnya menerapkan PHBS demi mencegah penularan Covid-19. Melaluii edukasi ini, diharapkan masyarakat memiliki pengetahuan dasar mengenai pentingnya menerapkan PHBS seperti menjalankan protokol kesehatan dan selalu mencuci tangan dengan baik dan benar di tengah kondisi pandemi saat ini sehingga secara langsung juga berkontribusi dalam menjaga kesehatan masyarakat dan mencegah penyebaran Covid-19.

\section{METODE \\ Waktu dan Lokasi Kegiatan}

Kegiatan edukasi ini dilaksanakan pada tanggal 20 Maret 2021, dimana peserta kegiatan ini adalah masyarakat Desa Air Salobar RT/RW 003/005 Kecamatan Nusaniwe Ambon. Kegiatan dilakukan pada masa pandemi dengan mengikuti protokol kesehatan yang berlaku, yaitu dengan menggunakan masker, mencuci tangan secara mandiri, dan menyediakan hand sanitizer untuk responden.

\section{Pelaksanaan Kegiatan}

Sebelum kegiatan dilaksanakan, terlebih dahulu dilakukan survei lokasi dengan tujuan untuk mengetahui sejauh mana pola kebiasaan masyarakat Desa Air Salobar RT/RW 003/005 dalam menerapkan PHBS dalam kehidupan sehari-hari, dan juga untuk mendapatkan informasi mengenai seberapa banyak masyarakat yang tertarik dan ingin berpatisipasi dalam kegiatan ini. Selanjutnya demi kelancaran jalannya kegiatan edukasi, dilakukan koordinasi dengan ketua RT 003/005 Desa Air Salobar untuk mendapatkan perizinan dan untuk menginformasikan secara resmi kepada masyarakat mengenai waktu dan lokasi dkegiatan. Kegiatan edukasi diawalii dengan penyampaian materi secara langsung kepada responden, dimana materi disampaikan secara lisan dengan bantuan proyektor/LCD, dilanjutkan dengan diskusi terarah atau sesi tanya jawab antara masyarakat dengan fasilitator, dan demonstrasi cara mencuci tangan yang baik dan benar oleh fasilitator dan praktiknya oleh responden. Monitoring dilakukan dengan memotivasi para responden untuk mempraktikkan cara mencuci tangan yang baik dan benar sesuai dengan arahan fasilitator dan mengevaluasi gerakan yang dilakukan dan mengoreksi secara langsung bila terdapat kekeliruan.

\section{HASIL DAN PEMBAHASAN}

Berdasarkan hasil survey awal untuk analisis situasi sebelum kegiatan edukasi dilaksanakan dan interview dengan Ketua RT dan beberapa masyarakat, didapatkan beberapa permasalahan yang ada pada masyarakat Desa Air Salobar RT/RW 003/005 terkait perilaku hidup bersih dan sehat (PHBS). Permasalahan-permasalahan tersebut diantaranya; a). Kurangnya pemahaman masyarakat tentang PHBS, b). Rendahnya kesadaran masyarakat dalam menerapkan 
PHBS, dan c). Belum adanya penyuluhan kepada masyarakat tentang pentingnya PHBS. Permasalahan ini tentunya menjadi persoalan yang harus segera diselesaikan guna meningkatan taraf kesehatan masyarakat dan untuk memutus mata rantai penyebaran Covid19.

Dalam rangka meningkatkan taraf kesehatan masyarakat, maka program PHBS yang telah dicanangkan oleh pemerintah melalui Kementerian Kesehatan harus selalu digalakkan di tengah masyarakat guna meningkatkan kesadaran masyarakat dalam menjaga kesehatan diri, keluarga dan lingkungan. Oleh karena itu, pemberian edukasi tentang pentingnya PHBS harus dilaksanakan pada semua level hingga ke masyarakat desa, khususnya Masyarakat Desa Air Salobar.

Kegiatan edukasi PHBS yang dilaksanakan kepada masyarakat Desa Air Salobar RT/RW 003/005 melibatkan 25 orang responden. Kegiatan ini berjalan dengan lancar dan masyarakat telihat sangat antusias, terbukti dengan hadirnya responden tepat sebelum kegiatan dimulai. Seluruh responden memperhatikan materi yang diberikan dengan seksama dan merespon dengan aktif pada sesi diskusi, serta mengikuti anjuran fasilitator untuk memperhatikan protokol kesehatan dengan memakai masker. Proses pemberian edukasi disajikan pada (Gambar 1 dan Gambar 2).

Edukasi PHBS diberikan kepada masyarakat secara lisan dimana materi disajikan dalam bentuk Slide Power Point dengan bantuan Proyektor/LCD, sehingga masyarakat yang mengikuti kegiatan edukasi dapat dengan mudah memahami pentingnya PHBS dan cara melaksanakannya. Sasaran dari edukasi in ialah agar materi edukasi PHBS tidak hanya dipahami oleh masyarakat tetapi juga diimplemetasikan dalam kehidupan seharihari. Disamping itu, untuk lebih meningkatkan kesadaran masyarakat dalam menjaga PHBS, pemberian materi juga disertai dengan contohcontoh atau dampak buruk dari melalaikan PHBS dalam kehidupan sehari-hari, serta contoh kasus yang terjadi di tengah-tengah masyarakat yang berdampak pada semakin berkembangnya penyebaran Covid-19. Selain itu, penggunaan Slide Power Point dalam kegiatan ini dimaksudkan untuk menumbuhkan anemo masyarakat mengenai materi edukasi. Menurut (Dahria \& Santoso, 2009), penggunaan Power Point dalam menyampaikan materi sangat memberikan kemudahan dalam membuat presentasi yang efektif, menarik dan professional sehingga responden dapat menangkap dengan jelas maksud yang ingin disampaikan oleh pemberi materi.

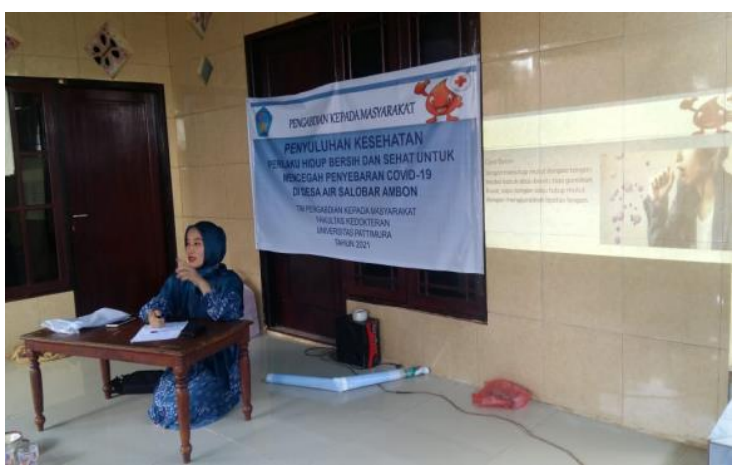

Gambar 1. Proses penyampaian materi

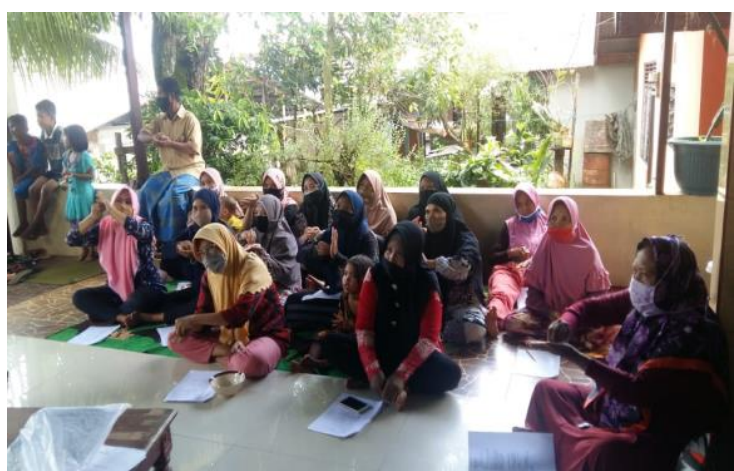

Gambar 2. Masyarakat Desa Air Salobar

antusias mendengarkan materi

Salah satu materi PHBS yang diedukasikan kepada masyarakat Desa Air Salobar adalah cara mencuci tangan yang baik dan benar seperti yang disajikan pada (Gambar 3 dan Gambar 4). Pengetahuan ini sangat diperlukan oleh responden mengingat kebanyakan masyarakat awam belum paham bagaimana cara mencuci tangan dengan baik dan benar. Selain itu, pengetahuan ini secara langsung juga berguna dalam mencegah penyebaran Covid-19 dengan selalu menjaga kebersihan diri, bukan hanya pada masa-masa pandemi tetapi untuk seterusnya. Masyaraka dapat dengan mudah memahami dan meniru tahapan mencuci tangan yang baik dan benar seperti yang didemonstrasikan oleh fasilitator. Hal ini ditunjukkan dengan berdirinya salah satu responden untuk mempraktikkan tahapan mencuci tangan yang baik dan benar secara mandiri.

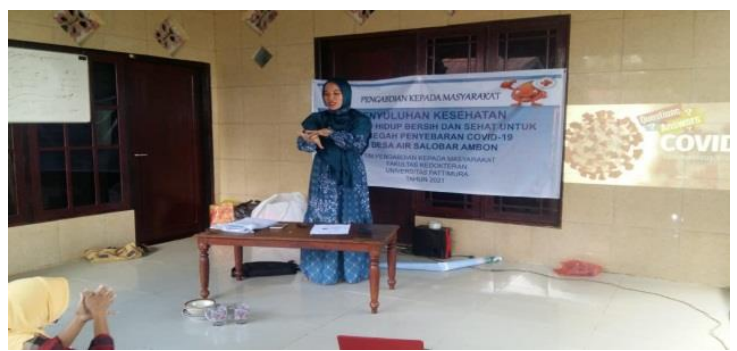

Gambar 3. Cara mencuci tangan yang baik dan benar didemonstrasikan oleh fasilitator 


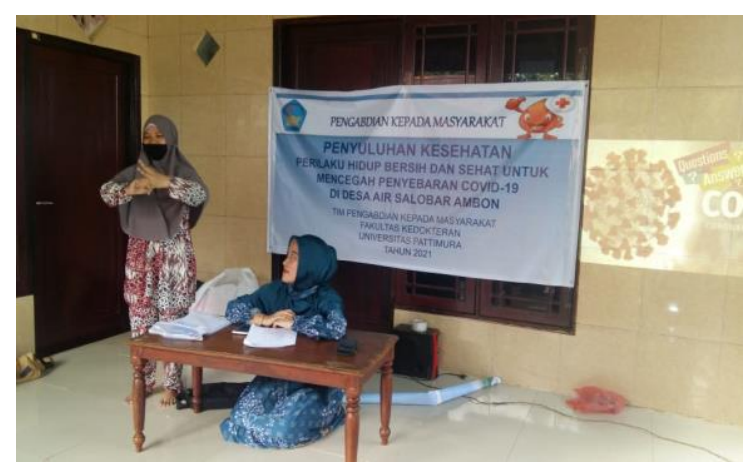

Gambar 4. Cara mencuci tangan yang baik dan benar dipraktikkan oleh responden

Keberhasilan dari suatu kegiatan edukasi bergantung kepada individu maupun masyarakat itu sendiri karena faktor penting yang mendukung keberhasilan dari suatu kegiatan edukasi ialah faktor perilaku. Menurut (Julianingsih et al., 2020), faktor perilaku dan budaya yang ada pada masyarakat merupakan faktor yang berpengaruh sangat signifikan terhadap keberhasilan PHBS pada masyarakat. Dengan menanamkan kesadaran kepada masyarakat mengenai pentingnya penerapan PHBS dalam kehidupan sehari-hari, tentunya hal ini menjadi kebiaaan yang melekat pada diri masyarakat seiring dengan bertambahnya waktu.

Pada saat pelaksanaan kegiatan edukasi, kendala utama yang dihadapi oleh fasilitator adalah ketidaktahuan responden mengenai bahaya covid-19 dan cenderung manganggap remeh. Hal ini terlihat dari acuh dan lalainya beberapa responden dalam menggunakan masker pada saat pelaksanaan kegiatan, sehingga fasilitator langsung memberikan masker serta mempersilakan para responden untuk menggunakan hand sanitizer dulu sebelum memulai kegiatan. Namun seiring bergulirnya kegiatan edukasi, masyarakat terlihat mulai menyadari dan termotivasi untuk mulai menjalankan protokol kesehatan selama kegiatan edukasi berlangsung.

Edukasi ini diharapkan menumbuhkan kesadaran dan mendorong masyarakat untuk manjaga kesehatannya dan keluarga sehingga juga berkontribusi terhadap pencegahan Covid19. Berbagai penelitian menunjukkan adanya pengaruh positif dari pemberian edukasi terhadap peningkatan pengetahuan masyarakat sehingga juga berpengaruh positif terhadap perilaku dan kebiasaan nasyarakat. Menurut (Zukmadani et al., 2020), edukasi PHBS yang diberikan secara langsung kepada masyarakat dapat meningkatkan pengetahuan masyarakat sebesar $11.01 \%$ setelah diberikan edukasi. Selain itu, survey yang dilakukan oleh (Nugrahaeni \& Permanasari, 2021), sehari sebelum dilaksanakan edukasi juga menunjukan adanya peningkatan pengetahuan masyarakat sebesar $18,18 \%$ setelah mendapatkan materi.

\section{SIMPULAN DAN SARAN Simpulan}

Kegiatan edukasi mengenai Perilaku Hidup Bersih dan Sehat (PHBS) kepada masyarakat Desa Air Salobar untuk mencegah penyebaran Covid-19 telah berhasil dilaksanakan dan masyarakat memberikan respon yang sangat baik ditunjukkan dengan antusiasme masyarakat tersebut dalam memberi pertanyaan seputar Covid-19 dan pencegahannya.

\section{Saran}

Perlu dilakukan kegiatan lebih lanjut untuk menganalisis tingkat pengetahuan masyarakat Desa Air Salobar mengenai pentingnya menerapkan PHBS dalam upaya mencegah penularan Covid-19.

\section{UCAPAN TERIMA KASIH}

Terima kasih disampaikan kepada Fakultas Kedokteran Universitas Pattimura yang menjadi payung atas pelaksanaan kegiatan ini.

\section{DAFTAR RUJUKAN}

Dahria, M., \& Santoso, I. (2009). Manfaat powerpoint dalam presentasi makalah. Jurnal SAINTIKOM, 6(1), 252-275.

Huang, C., Wang, Y., Li, X., Ren, L., Zhao, J., Hu, Y., Zhang, L., Fan, G., Xu, J., Gu, X., Cheng, Z., Yu, T., Xia, J., Wei, Y., Wu, W., Xie, X., Yin, W., Li, H., Liu, M., ... Cao, B. (2020). Clinical features of patients infected with 2019 novel coronavirus in Wuhan, China. The Lancet, 395(10223), 497-506. https://doi.org/10.1016/S01406736(20)30183-5

Kementerian Kesehatan Republik Indonesia. Infeksi https://covid19.kemkes.go.id/ situasiinfeksi-emerging/situasi-terkiniperkembangan-coronavirus-diseasecovid-19-23-maret-2021

Julianingsih, V., Karjoso, T. K., \& Harahap, E. S. (2020). Faktor-Faktor Yang Berhubungan dengan PHBS di Pekanbaru. Health Care: Jurnal Kesehatan, 9(1), 9-16. https://doi.org/10.36763/healthcare.v9i1.5 6

Nugrahaeni, F., \& Permanasari, E. D. (2021). Edukasi Perilaku Hidup Bersih Sehat dan Pembagian Masker, Handsanitizer kepada Warga Jatisari. Abdimasku: Jurnal Pengabdian Masyarakat, 4(1), 1. https://doi.org/10.33633/ja.v4i1.162 
Razi, F., Yulianty, V., Amani, S. A., \& Fauzia, J. H. (2020). COVID-19: Buku Kesehatan Mandiri Untuk Sahabat. PD Prokami Kota Depok, 27

Singhal, T. (2021). A Review on COVID-19. Indian $J$ Pediatr, 924(April), 25-42. https://doi.org/10.1007/978-3-030-601881_2

Zukmadani, A. Y., Karyadi, B., \& Kasrina. (2020). Edukasi Perilaku Hidup Bersih dan Sehat (PHBS) dalam Pencegahan COVID-19 Kepada Anak-Anak di Panti Asuhan. Jurnal Pengabdian Masyarakat, 3(1), 68-76. https://doi.org/10.29303/jpmpi.v3i1.440 